\title{
TREATMENT OF NATURAL GAS BY ADSORPTION OF $\mathrm{CO}_{2}$
}

\author{
Kristýna Hádková*, Viktor Tekáč, Karel Ciahotný, ZdeněK BeŇo, \\ VERONIKA VRBOVÁ
}

\author{
Department of Gas, Coke and Air Protection, University of Chemistry and Technology, Prague, Technická 5, \\ Praha 6, 166 28, Czech Republic \\ * corresponding author: kristyna.hadkova@vscht.cz
}

\begin{abstract}
Apart from burning, one of the possible uses of natural gas is as a fuel for motor vehicles. There are two types of fuel from natural gas - CNG (Compressed Natural Gas) or LNG (Liquefied Natural Gas). Liquefaction of natural gas is carried out for transport by tankers, which are an alternative to long-distance gas pipelines, as well as for transport over short distance, using LNG as a fuel for motor vehicles. A gas adjustment is necessary to get LNG.

As an important part of the necessary adjustment of natural gas to get LNG, a reduction of $\mathrm{CO}_{2}$ is needed. There is a danger of the carbon dioxide freezing during the gas cooling. This work deals with the testing of adsorption removal of $\mathrm{CO}_{2}$ from natural gas. The aim of these measurements was to find a suitable adsorbent for $\mathrm{CO}_{2}$ removal from natural gas.

Two different types of adsorbents were tested: activated carbon and molecular sieve. The adsorption properties of the selected adsorbents were tested and compared. The breakthrough curves for $\mathrm{CO}_{2}$ for both adsorbents were measured. The conditions of the testing were estimated according to conditions at a gas regulation station $-4.0 \mathrm{MPa}$ pressure and $8^{\circ} \mathrm{C}$ temperature. Natural gas was simulated by model gas mixture during the tests. The breakthrough volume was set as the gas volume passing through the adsorber up to the $\mathrm{CO} 2$ concentration of $300 \mathrm{ml} / \mathrm{m}^{3}$ in the exhaust gas. The thermal and pressure desorption of $\mathrm{CO}_{2}$ from saturated adsorbents were also tested after the adsorption.
\end{abstract}

KEYWORDS: natural gas treatment; adsorption; $\mathrm{CO}_{2}$ removal.

\section{INTRODUCTION}

There are a few possibilities how to use natural gas. Fuel for motor vehicles is one of them. Natural gas can be used as CNG (Compressed Natural Gas) or as LNG (Liquefied Natural Gas). LNG is very important for the international trade of natural gas and this importance will grow [1. An adjustment is needed during the liquefaction of natural gas; $\mathrm{CO}_{2}$ removal is one of them, because $\mathrm{CO}_{2}$ can freeze during the gas cooling process. $\mathrm{CO}_{2}$ has to be removed also because if there is water in natural gas acid can be formed and it leads to corrosion of pipelines [1]. $\mathrm{CO}_{2}$ removal can be carried out by several ways - adsorption, absorption, physical scrubbing or cryogenic separation.

Adsorptive separation of $\mathrm{CO}_{2}$ was chosen for this work. Two types of adsorbent were used for the experiments - activated carbon $\mathrm{C} 46$ and $13 \mathrm{X}$ zeolite molecular sieve. The breakthrough volume of $\mathrm{CO} 2$ in exhaust gas was set at $300 \mathrm{ml} / \mathrm{m}^{3}$. The temperature and pressure were set according to common conditions at the pressure regulation station at the gas pipeline: $8^{\circ} \mathrm{C}$ and $4.0 \mathrm{MPa}[2$.

\section{THEORY}

\subsection{LNG}

LNG is liquefied natural gas; an odorless liquid cooled to $-162^{\circ} \mathrm{C}$ at atmospheric pressure. The volume of liquefied natural gas is 600 times smaller than the same amount of natural gas in gaseous state. Because of its smaller volume, LNG is better for long distance transport if there is no gas pipeline [3, 4].

\subsection{Adsorption}

Adsorption is a phenomenon during which molecules of gas, vapor or liquid are captured on a solid surface. There are two types of adsorption which work on different principles of bounding forces - physical sorption and chemical sorption. In the case of physical sorption, the adsorption is based on Van der Waals forces. The bounds are not specific, the bounds are not chemical and molecules can be adsorbed in more layers [5, 6. In the case of chemical sorption, the bounds are chemical. The bounds are specific, and molecules are captured only at active centers. The molecules can thus be captured only in one layer. Unlike in the case of physical sorption, activation energy is needed [5, 7]. Regeneration of an adsorbent can be realized due to different adsorption capacities at different temperatures (therma-swing adsorption) or at different pressures (pressure-swing adsorption) [1]. PSA technology doesn't require use of chemicals (like amine or other solvents in the case of absorbtion technology), heat is not used for the regeneration (that means low energy intensity) and the PSA units are suitable for big and small technological arrangement 8 . 


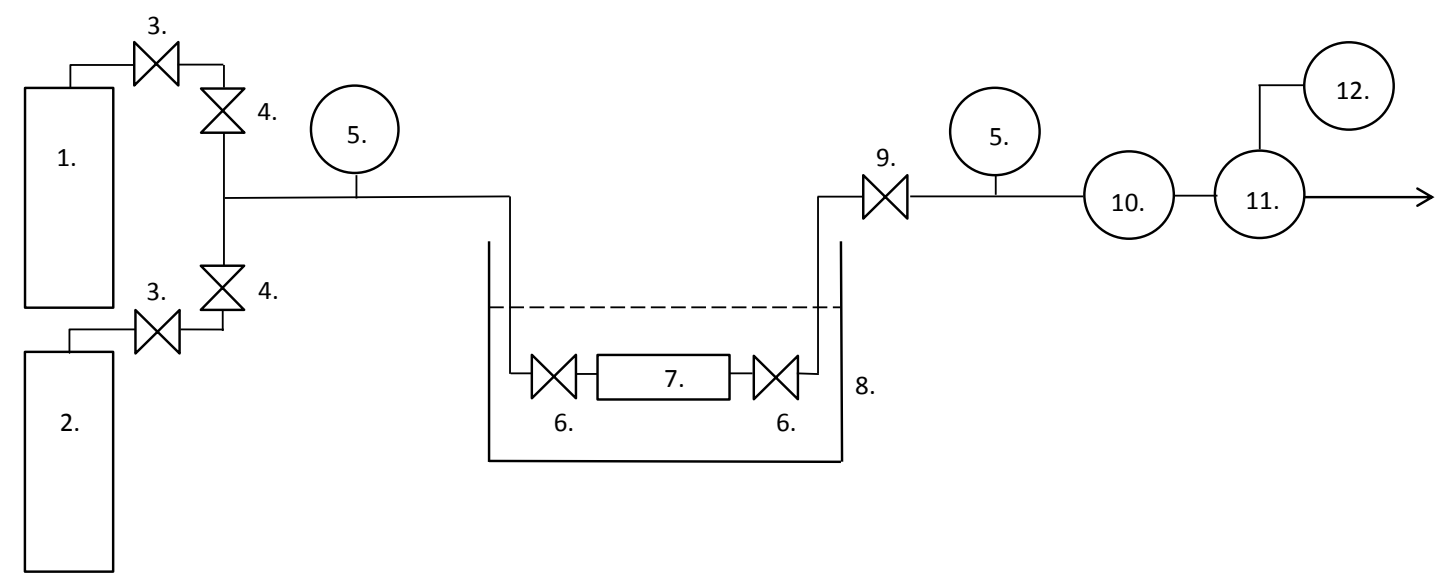

FiguRE 1. The apparatus for the breakthrough curves measuring: (1) cylinder containing the gas mixture; (2) cylinder containing nitrogen; (3) reducing valves; (4) switching valves; (5) manometer; (6) ball valves; (7) adsorber; (8) cooling bath; (9) needle valve; (10) gas flow meter; (11) analyzer; (12) computer.

\begin{tabular}{lc}
\hline Methane & 86.3 \\
Ethane & 6.97 \\
Propane & 0.784 \\
Butane & 0.786 \\
CO $_{2}$ & 2.03 \\
$\mathbf{N}_{2}$ & 3.13 \\
\hline
\end{tabular}

TABle 1. Composition of the inlet gas (Linde Gas a.s.) $[\mathrm{mol} \%]$.

\section{EXPERIMENTS}

\subsection{AdSORPTION}

The aim of the experiments was to compare selected adsorbents for the removal of $\mathrm{CO}_{2}$ from natural gas. The breakthrough curves of $\mathrm{CO}_{2}$ were measured with the laboratory apparatus. The breakthrough volume was set at $300 \mathrm{ml} / \mathrm{m}^{3}$ of $\mathrm{CO}_{2}$ in exhaust gas. Adsorption was carried out at $8^{\circ} \mathrm{C}$ and at a pressure of 4.0 MPa. The gas mixture used is described in Tab. 1 .

The synthetic 13X zeolite molecular sieve from Sigma - Aldrich and activated carbon C46 from Silcarbon Aktivkohle were tested as adsorbents. The inner surface and pore volume of these adsorbents were measured by BET method at Coulter SA 3100. These properties are described in Tab. 2

Fig. 1 shows the apparatus used to measure the breakthrough curves of $\mathrm{CO}_{2}$. Two cylinders belong to the apparatus. The first of them contains the tested gaseous mixture and the second contains nitrogen, to purge the apparatus. There are reducing valves where the output pressure of $4.0 \mathrm{MPa}$ can be set. Then there are changeover valves to purge the apparatus by nitrogen or to use a model gas mixture. The pressure of the inlet gas is measured by the manometer, which is connected as the next part. Then the gas flows into an adsorber filled with the tested adsorbent. The adsorber is equipped with valves which close it at both, and it is placed in a

\begin{tabular}{lcc}
\hline & MS 13X & AC C46 \\
\hline Inner surface $\left[\mathrm{m}^{2} / \mathrm{g}\right]$ & 533 & 1258 \\
Pore volume $[\mathrm{ml} / \mathrm{g}]$ & 0.346 & 0.589 \\
\hline
\end{tabular}

TABLE 2. Inner surface and pore volume of the adsorbents.

bath cooled to $8^{\circ} \mathrm{C}$. Then there is a needle valve which reduces the gas pressure in the apparatus to atmospheric pressure. The next part of the apparatus is a manometer, than there is a flow meter and at the end is the analyzer which is connected to the computer.

The apparatus was always first purged with nitrogen, and then the desired gas flow was set. The flow rates of gases at each measurement were slightly different due to the low sensitivity of the control element. The flow was set at $4.1 \mathrm{l} / \mathrm{min}$ in the case of the $13 \mathrm{X}$ molecular sieve and at $3.4 \mathrm{l} / \mathrm{min}$ in the case of activated carbon $\mathrm{C} 46$. The samples were activated by being heated to $150{ }^{\circ} \mathrm{C}$ for 8 hours before the measuring. After being flushed with nitrogen, the model gas mixture was charged into the apparatus. The content of $\mathrm{CO}_{2}$ in the exhaust gas was monitored by FTIR analyzer Nicolet Antaris IGS. When the limit volume of $300 \mathrm{ml} / \mathrm{min} \mathrm{CO}_{2}$ was exceeded, the time and volume of gas flowing through were recorded. The experiment continued until the saturation of the adsorbent; that is, until the $\mathrm{CO}_{2}$ content in the exhaust gas stops increasing.

Desorption of $\mathrm{CO}_{2}$ from the saturated adsorbent was also carried out. Both pressure switch desorption by low pressure and thermal desorption by elevated temperature were realized. During the pressure switch desorption the adsorber was connected to a vacuum pump for 1 hour after depressurization to atmospheric pressure. In the case of thermal desorption, saturated adsorbents were regenerated at $150{ }^{\circ} \mathrm{C}$ for 8 hours. 


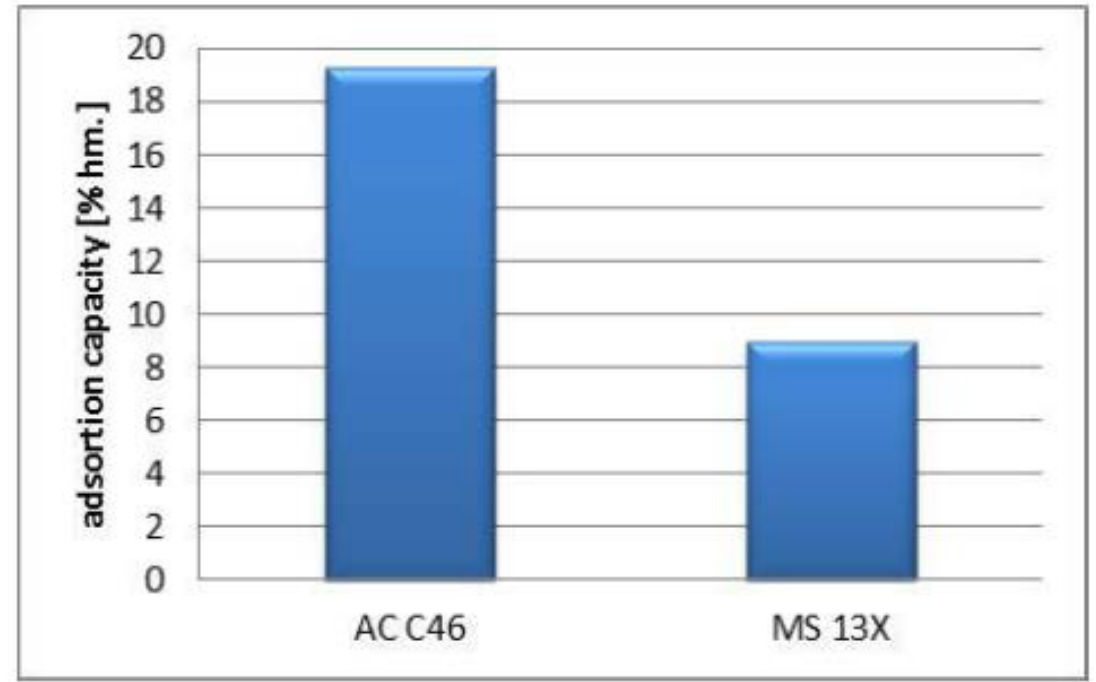

Figure 2. The total adsorption capacity at the tested adsorbents by $8^{\circ} \mathrm{C}$.

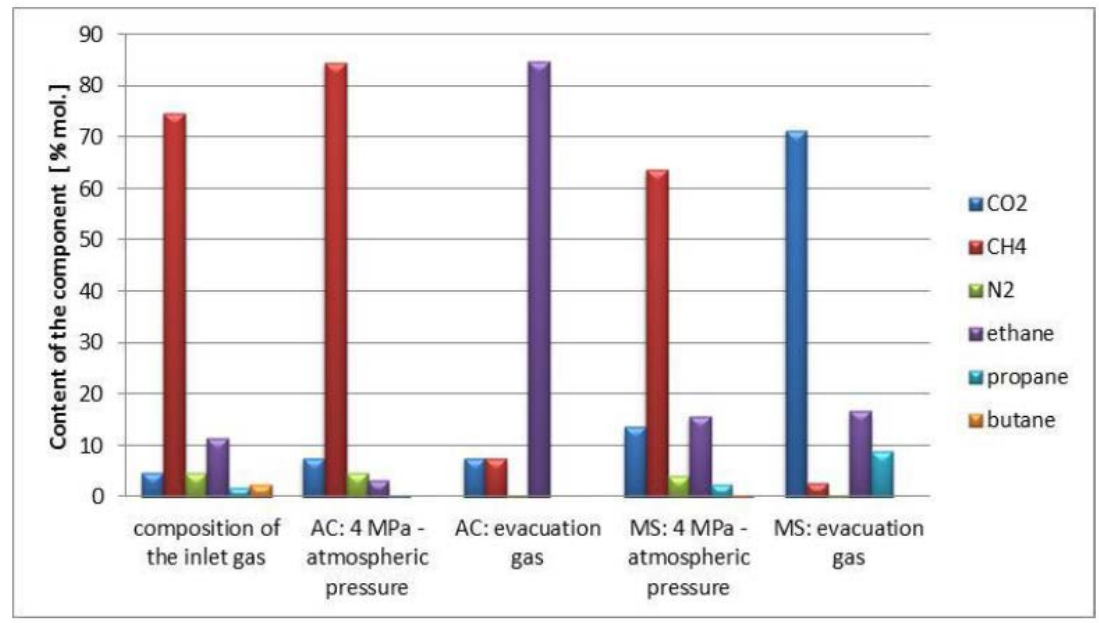

FiguRE 3. Activated carbon C46 and 13X molecular sieve: content of the components in gas extracted by reduction of the pressure from 4.0 MPa to atmospheric pressure and in gas extracted by evacuation.

\subsection{Desorption}

The desorption of adsorbed gas from the $13 \mathrm{X}$ molecular sieve and activated carbon C46 was also tested. During the thermal desorption the adsorber was disconnected from the apparatus, the pressure was reduced from 4.0 MPa to atmospheric pressure, and the adsorbent was then regenerated at $150^{\circ} \mathrm{C}$ for 8 hours, at atmospheric pressure.

In the case of pressure desorption, the ball valves were closed; the adsorber was disconnected from the apparatus and weighted. After the depressurization to atmospheric pressure, the adsorber was weighted again and subsequently the vacuum pump was connected for 1 hour. The gas from depressurization and from evacuation was collected and analyzed on a Hewlett-Packard HP 6890 chromatograph. The resulting adsorbed gas mass was the difference between the weight after the measurement (the adsorbent was saturated) and the weight before the measurement.
The mass of the gas located in the space between the adsorbent particles was subtracted from the resulting mass. This mass value is an important part of the final weight (in this case about $4 \mathrm{~g}$ of gas) of the gas at a pressure of 4.0 MPa.

\section{RESUlts AND DisCUSSION}

The results of the total adsorption capacities of the tested adsorbents AC C46 and MS 3X are shown in Fig. 2. These capacities were determined by weighing the adsorber.

This figure shows that the adsorption capacity of the 13X molecular sieve was $9 \mathrm{wt} \%$ and the activated carbon has an adsorption capacity higher than $19 \mathrm{wt} \%$. These results agree with the BET physical adsorption theory: the inner surface and pore volume of activated carbon $\mathrm{C} 46$ are higher than those of the molecular sieve. 


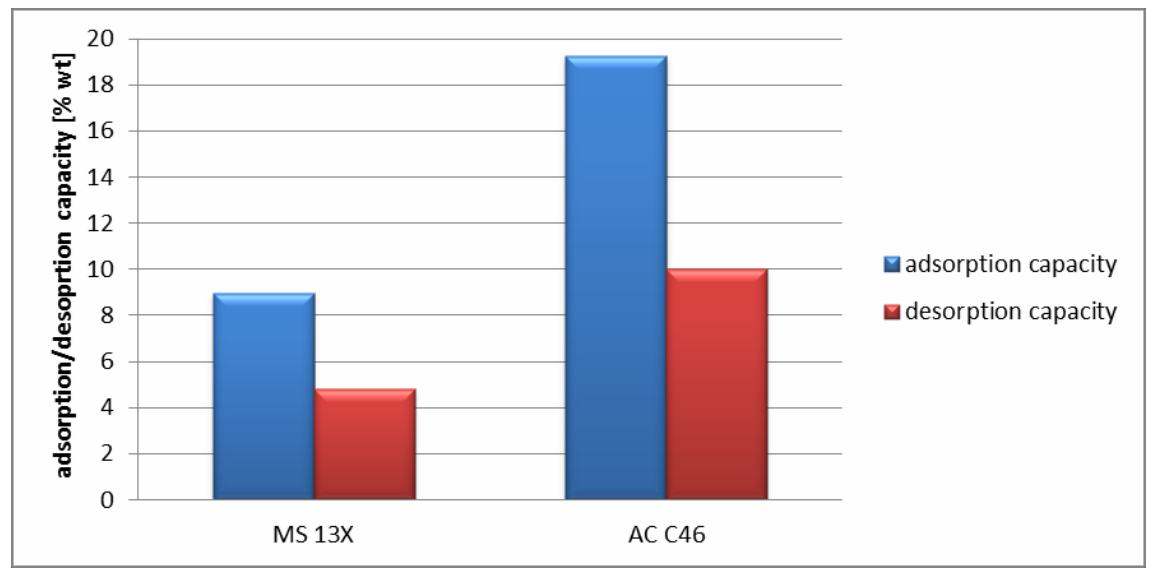

FiguRE 4. Adsorption and desorption capacity - pressure desorption.

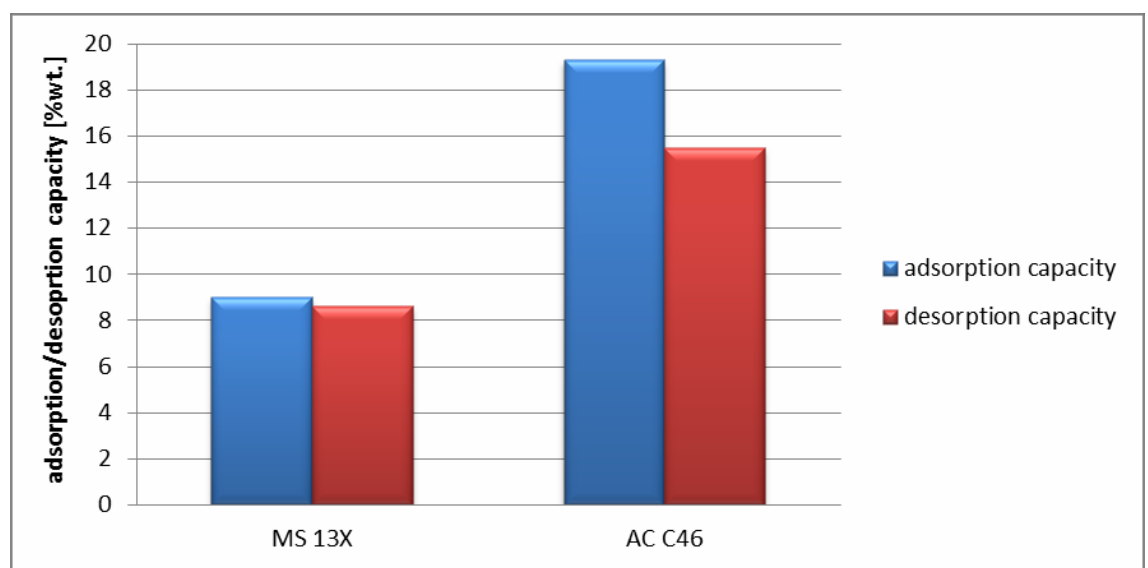

FiguRE 5. Adsorption and desorption capacity - thermal desorption.

This adsorption capacity shows the total adsorption capacity of all adsorbed components of the gas mixture; it is not clear whether it is only $\mathrm{CO}_{2}$ or whether other gases are also adsorbed. An analysis of the adsorbed gas (extracted by reduction of the pressure from 4.0 MPa to atmospheric pressure and then by evacuation) was carried out. These gases were analyzed at a gas chromatograph Hewlett-Packard HP 6890 equipped with FID and TCD detectors. The composition of the gas taken out by reduction of pressure from $4.0 \mathrm{MPa}$ to atmospheric pressure and the composition of the gas extracted by evacuation are shown in Fig. 3 for the 13X molecular sieve and the activated carbon $\mathrm{C} 46$.

The composition of inlet gas is shown in the first group of columns. The exact gas composition values are described in Tab. 1 .

The amount of $\mathrm{CO}_{2}$ grows slightly in the gas from depressurization and from evacuation in the case of activated carbon. $\mathrm{CO}_{2}$ is particularly adsorbed and it is released during the pressure reduction from $4.0 \mathrm{MPa}$ to atmospheric pressure and then also during the evacuation. In the case of the $13 \mathrm{X}$ molecular sieve, the content of $\mathrm{CO}_{2}$ grows slightly in the exhaust gas in comparison to feed gas. It can be assumed that during the pressure reduction to atmospheric pressure in the adsorber a partial release of $\mathrm{CO}_{2}$ occurs. A dominant amount of $\mathrm{CO}_{2}$ remains adsorbed on the surface of the molecular sieve at atmospheric pressure; $\mathrm{CO}_{2}$ releases adsorbent during the evacuation.

In the case of activated carbon $\mathrm{C} 46$, the methane content is slightly higher in depressurization gas than in the inlet gas; methane is adsorbed on the activated carbon surface and it is released during the pressure reduction from $4.0 \mathrm{MPa}$ to atmospheric pressure. Methane is also desorbed during the evacuation. The methane content in the gas from the depressurization of the 13X molecular sieve compared to the inlet gas decreases only slightly; there is no high adsorption of methane on the molecular sieve surface. The small amount of adsorbed methane is released during the evacuation.

The amount of nitrogen in depressurization gas of activated carbon is comparable to the amount of nitrogen in the inlet gas, and there is almost no nitrogen in the evacuation gas. It can be assumed that nitrogen is not adsorbed on the activated carbon surface. In the case of the molecular sieve, the amount of nitrogen in exhaust gas is comparable to the amount in inlet gas. There is also no nitrogen in the gas from the evacuation of the adsorbent. Thus nitrogen is nearly not adsorbed. 
In the case of activated carbon, the amount of ethane in depressurization gas is noticeably lower than in the inlet gas, and it increases slightly in the evacuation gas. Ethane is adsorbed on activated carbon and it is released during the evacuation, but almost not during the depressurization. In the case of the molecular sieve, the amount of ethane is higher in the depressurization gas than in the inlet gas; ethane is particularly adsorbed on the molecular sieve surface and it is released during the pressure reduction from 4.0 $\mathrm{MPa}$ to atmospheric pressure and also during the evacuation.

Propane and butane almost do not occur in the gas from depressurization and from evacuation of activated carbon; it can be assumed that propane and butane are strongly adsorbed on activated carbon surface; that they are not released during any pressure reduction. In the case of molecular sieve the amount of propane in the gas from depressurization is comparable to the inlet gas. The amount of propane grows significantly in the gas from evacuation; the propane is adsorbed on the molecular sieve surface and it is released during the evacuation. Butane is present only in the inlet gas, it is almost absent in the depressurization gas and also in the gas from evacuation. Butane is bound so strongly to the molecular sieve surface that it is not released during any pressure reduction.

\subsection{Desorption}

The 13X molecular sieve and activated carbon C46 were also tested for desorption of adsorbed gas. The results of the pressure desorption are shown in Fig. 4.

In the case of pressure desorption the desorption amount is almost $5 \mathrm{wt} \%$ for the $13 \mathrm{X}$ molecular sieve. The desorption amount for activated carbon C46 reaches $10 \mathrm{wt} \%$. For both samples, it is about half of the adsorbed amount. Fig 4 shows that it is not possible to desorb the full captured amount of adsorbed components. Propane and butane and probably part of the adsorbed $\mathrm{CO}_{2}$ are adsorbed mainly in the smallest pores from which they are not released.

During the thermal desorption the adsorbent was regenerated at $150{ }^{\circ} \mathrm{C}$ for 8 hours at atmospheric pressure. The results of the thermal desorption are shown in Fig. 5 .

In the case of thermal desorption the desorption amount reaches $9 \mathrm{wt} \%$ for the $13 \mathrm{X}$ molecular sieve; this value is close to the adsorption capacity of the molecular sieve. Almost all adsorbed gas is released.

The desorption capacity is almost $16 \mathrm{wt} \%$ in the case of activated carbon. Almost $80 \mathrm{wt} \%$ of adsorbed gas is released.

\section{Conclusions}

The experiments show that activated carbon $\mathrm{C} 46$ has a higher adsorption capacity for components of gas mixture. Activated carbon also has a greater pore volume and larger inner surface. However, the adsorption capacity does not only involve $\mathrm{CO}_{2}$; mainly propane and butane are adsorbed. The content of ethane in gas from desorption reaches almost $85 \mathrm{wt} \%$ and the content of $\mathrm{CO}_{2}$ is lower than $10 \mathrm{wt} \%$. In the case of the molecular sieve there is more than $70 \mathrm{wt} \%$ of $\mathrm{CO}_{2}$ in adsorbed gas. Finally, the molecular sieve has a higher adsorption capacity for $\mathrm{CO}_{2}$ than activated carbon C46.

Both adsorbents were also tested for desorption of adsorbed gases. Almost all adsorbed gases were released by thermal desorption from the $13 \mathrm{X}$ molecular sieve and almost $80 \mathrm{wt} \%$ adsorbed gas was desorbed from activated carbon C46. The pressure swing desorption was not comparably successful; only about a half of the adsorbed gas was released.

The 13X molecular sieve is a suitable adsorbent for $\mathrm{CO}_{2}$ from natural gas. $\mathrm{CO}_{2}$ is adsorbed mainly on the surface of the molecular sieve and it is also effectively desorbed by thermal desorption. However, activated carbon can be used for propane and butane removal from natural gas.

\section{ACKNOWLEDGEMENTS}

Financial support from specific university research (MSMT No 20/2013).

\section{REFERENCES}

[1] Rufford, T. E.; Smart, S.; Watson, G. C. Y.; Graham, B. F.; Boxall, J.; Diniz da Costa, J. C.; May, E. F. The removal of $\mathrm{CO}_{2}$ and $\mathrm{N}_{2}$ from natural gas - A review of conventional and emerging process technologies. Journal of Petroleum Science and Engineering 94, 123-154, 2011.

[2] Quack, H. Koncepční řešení malého účinného zdroje LNG. Plyn 92 (12), 272-274, 2012.

[3] Šebor, G.; Pospíšil, M.; Žákovec, M.

Technicko-ekonomická analýza vhodných alternativních paliv v dopravě; Praha, 2006 (in Czech).

[4] Vše o CNG - Alternativní pohonné hmoty Zkapalněný zemní plyn. CNG. http:

//www.cng.cz/cs/alternativni-pohonne-hmoty-126/ [2014-02-25] (in Czech)

[5] Bureš, M.; Černý, Č.; Chuchvalec, P. Fyzikální chemie II, 1st ed.; VŠCHT: Praha, 1994 (in Czech).

[6] McKetta, J. Encyklopedia of chemical processing and design, vol. 2; New York and Basel, 1977.

[7] Vrbová, V. Testování nových druhư adsorpčních materiálů pro odstraňování organických látek z plynů. Semestrální projekt, VŠCHT Praha, květen 2007 (in Czech).

[8] Tagliabue, M.; Farrusseng, D.; Valencia, S.; Aguado, S.; Ravon, U.; Rizzo, C.; Corma, A.; Mirodatos, C. Natural gas treating by selective adsorption: Mateial science and chemical engineering interplay. Chemical Engineering Journal 155, 553-566, 2009. 